Editor's Note: Beginning with this volume, Norrh Carolina Libraries will publish at least one article that is unrelated to each issue's specific theme. The Editorial Board is delighted to introduce this feature to address the increase in excellent unsolicited manuscripts which merit publication.

\title{
Whole Language and Its Effect on the School Library Media Center
}

\author{
by Susan Prillaman
}

\section{1}

n educational movement, which began quietly enough in New Zealand, Australia and the United Kingdom in the 1970 s under the umbrella term of "teaching language across the curriculum," became a rallying cry for educators throughout the United States and Canada in the 1980s. It will likely continue unabated in the 1990s. In North America, it is called Whole Language. There are literally hundreds of journal articles and many books being published to describe what it is, what it isn't, and how to do it. This paper examines the evolution of Whole Language, its current theory and practices, as well as its effect on the school library media center.

\section{A Definition}

The best working definition of Whole Language this author has come across is:

It is not a practice. It is a set of beliefs, a perspective. Practices such as journals or thematic units become Whole Language because the teacher has a set of particular beliefs and intentions ... Just as babies learn to speak language through hearing and using it, so reading and writing in older children should be acquired in the same way, as an integral part of the functioning community. ${ }^{1}$

Whole Language is also the basis for a grassroots movement that has been led on the local level by teachers and librarians who have perhaps held this world-view of teaching for years and now have a support group locally, nationally, and internationally. Educators, including media specialists, who subscribe to Whole Language generally share these beliefs: children learn to read by reading; reading is part of the language acquisition process that also includes listening, writing, and speaking; and learning in any one of these areas of language assists the learner in the other two.

\section{Evolution}

In the 1960s, linguists Noam Chomsky and Michael Halliday and a reading specialist, Marie Clay, published their findings on research focused on language acquisition and use. Their conclusions, which were to shape education for decades to follow, showed that if children are immersed in significant and real language experiences, they absorb it and can use it.

In the 1970 s and 1980 s there was an international exchange of ideas, practices, and research bearing on the application of the linguistics research and findings. New Zealand, Australia, and Great Britain, with Canada following suit, became the acknowledged leaders in "language across the curriculum." Researchers here and abroad took Chomsky's, Halliday's, and Clay's findings and looked at reading comprehension, story grammar, and other aspects of how children learn to read. "The work of the Center for the Study of Reading, the National Assessment of Educational Progress, as well as the Wolf, Huck, \& King study on critical reading, convinced us that children need well-constructed stories [emphasis mine] in order to make sense out of print."2 The importance of the fundamental need of a well-written story, narrative, or a real language experience when working with children is underscored.

Teachers and librarians are having their long-held beliefs about the importance of early language experiences borne out by the research of people like Gordon Wells, who reported his findings in the Meaning Makers. He asked the questions, "What is it that is required then, for children to be able to extend their command of language to include the written mode? Are there preschool experiences that prepare some children more effectively than others to take the learning of writing in their stride? If so, what sort of experiences at school can best help children to make up for what they have missed at home?"3 His most poignant evidence reveals that the simple act of reading aloud real literature to young children makes a significant difference in how they continue to acquire and use language in a school setting. Educator and author, Jim Trelease, has added a second volume to The Read-Aloud Handbook that can be used to put into practice what Wells has proven with his research. 4

In the United States, Kenneth Goodman has been a leading proponent of the Whole Language Movement and has assisted in its adoption by teachers and librarians. His best known book, What's Whole in Whole Language 5 is an overly emotional and leftist political appeal for Whole Language to be adopted everywhere by everyone for everybody. However, if the reader ignores the pathos and politics and reads the text, it is easy to see how it has had its effect on spreading "the gospel." (Unfortunately, there are no footnotes or bibliography from which those interested readers could find further evidence to support his claims.) His wife, Yetta Goodman, as President of the National Council of Teachers of English (NCTE) and Dorothy Strickland, as President of the International Reading Association, were very active in organizing an effort to get the results of important research on language acquisition out to the troops in the frontlines (i.e., classroom teachers and librarians). Goodman and Strickland, who were followed by Sheila Fitzgerald (NCTE) and Bernice Cullinan (IRA), organized a group to plan Impact Conferences and to publish and distribute relevant research.6 In California and Canada, Reading Initiatives were begun wherein teachers and librarians worked together to develop programs that were successful in bringing authentic literature into the curriculum and, perhaps, more joy into the learning environment. Of equal interest to the organized approach to disseminating information on language across the curriculum, is the development of support groups across the country. One such approach is 
known as TAWL, Teachers Applying Whole Language. It began as a small San Francisco organization and has grown rapidly into an international federation. It may turn out that the TAWLs of the world will actually have a more immediate effect in changing how the educational establishment provides a satisfying learning environment.

Has there been a change already in how states are providing an "environment rich in literacy events" and teaching language across the curriculum? Is it an indication of how or if Whole Language is being applied? Information from the "Reading Initiative Survey" of 1988 shows that seven states have begun literature/literacy initiatives (North Carolina is one them); sixteen report integrating language arts; fourteen states have begun local literature-based programs; and three states (Missouri, New Mexico and South Dakota) report no change in the basic skills approach. ${ }^{7}$ The author believes that Arizona is the leader in implementing a language across the curriculum.

What isn't Whole Language? If a librarian and a teacher were to take seriously the publishers' advertisements that come across their desks, they might believe that you can buy It in a kit, workbook, or basal text. Whole Language proponents do encourage a "print rich environment" but they also encourage "authentic literacy events" rather than those contrived in programmed learning, skills sheets, or basal texts. Whole Language purists believe that basal texts would only be examined in a Whole Language classroom if the student were studying changes in school culture over time. Altwerger et al. conclude that Whole Language isn't: ${ }^{8}$

(1) the whole-word approach that is taught as a subskill of reading. Whole Language is not another term for teaching skills in context.

(2) the Language Experience Approach where the teacher

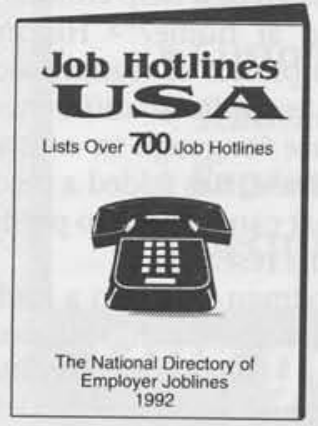

\section{Just Published!}

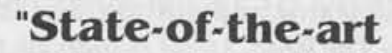
reference help for today's job seeker."

ISBN 1-881587-00-2

Job hunters need your library services now more than ever. Unknown to many of them, employers advertise thousands of jobs on recorded telephone messages every week. Job Hotlines USA, The National Directory of Employer Joblines, identifies over 700 hardto-find employer jobline telephone numbers.

- Callers dial direct to each employer. No "900" numbers. No third parties.

- Covers business, gov't., industry, education, healthcare \& military.

- All job categories, nationwide.

Published by Career Communications, Inc. Job Hotlines USA is available for \$19.95 postpaid. Call (215) 256-3134 to order. Or write 500 Main St., P.O. Box 169, Harleysville, PA 19438 for more information. allows a student to dictate a story to her because "the implicit notion about writing...was that it amounted to taking dictation from oneself (i.e., composing occurred prior to transcribing)." Whole Language practitioners have come to believe that the act of writing and meaning making occur simultaneously.

(3) Open Classrooms or Open Education that became all the rage in the 1960s and 1970s, albeit these authors believe that Open Education was a necessary precursor to Whole Language. Both movements held that the learners should be active participants in the planning and execution of instruction.

\section{The Montessori Connection}

As this author studied Whole Language, she observed continued evidence of a similarity between the Montessori approach to literacy and Whole Language. After re-reading some of Maria Montessori's works and those of her proponents and practitioners, these connections became obvious:

1. A belief held by both Whole Language and Montessori philosophies that a child who draws will eventually write letters; that drawing is a natural precedent to writing.

2. Whole Language proponents hold that children learn to read and write in the same way (i.e., wholistically) that they learn to speak the language. Montessori states, "As spoken language is at the same time a natural function of man and an instrument which he utilizes for social ends, so written language may be considered in itself, in its formation, as an organic ensemble of new mechanisms which are established in the nervous system and as an instrument which may be utilized for social ends." 9

3. A Whole Language classroom and a Montessori classroom are both child-centered rather than teacher-centered. The following description, taken from a Montessori book, really describes both types of classrooms: "The teacher serves the child. She prepares the environment, creating an orderly, attractive, and interesting classroom. She establishes the structure or ground rules for behavior and sees that they are followed. She gives individual and group lessons on the use of materials. She frees the child, within the structure of the classroom, to move, to talk, to make choices, and to become interested in working with the materials." 10

4. Learning to read in both types of classrooms depends upon the child's first learning to recognize the words for real objects in the classroom environment. Montessori states, "I do not consider as reading the test which the child makes when he verifies the word he has written ... What I understand by reading is the interpretation of an idea from the written signs ... writing aids the physiological language and reading aids the social language ... We begin then with ... the reading of names of objects which are well known and present ... Reading, if it is to teach the child to receive an idea, should be mental not vocal."11

5 . Reading out loud daily to students from a real story as opposed to a basal text is an important part of the day for both types of classrooms.

6. Science, mathematics, geography, music, and art are taught in both types of classrooms with real materials and real experiences. Often the lessons are designed to integrate and relate them one to another.

This "cursory glance," as opposed to an in-depth study of the relationship between Whole Language and Montessori, is presented simply to show that both methods work because they respect the child's spirit, innate curiosity, and growing intellect. Practitioners of Whole Language could very well learn useful methods from studying Montessori methods that have been developed over the past ninety years.

\section{Effect on the Library Media Center}

Whole Language may be relegated to the heap of discarded educational bandwagons if it is not studied, researched, and 
implemented using the basic strategies that are already known concerning successful change in the school environment. Change is a process, not an event. It can be measured through time with the involvement of people. Jean Brown states that "there are three distinct phases to planned change :... adoption, implementation, and continuation."12 Administrators are key elements at the adoption and continuation phase; teachers and media specialists are the key element in the implementation phase. When Whole Language is successfully adopted in a school, the media specialist can play a central role if she has substantial knowledge of Whole Language and how it is fostered in a classroom setting, and if she is able to provide instruction in specific skills either by modeling it in her own instruction or by applying it in cooperative planning sessions. In all likelihood, in a Whole Language school, the librarian-teacher will continue to be a strong advocate for literacy as well as develop a strong partnership with the teachers in planning curriculum in terms of resource-based learning.

\section{A Whole Language Library Media Center}

The media specialist can fill a unique role as instructional leader in the school. It is imperative, though, to have a clear vision of what change is desired and how to get there. Classroom teachers can be overburdened with the sheer enormity of their day-to-day tasks. The social problems of the 1980 s and 1990 s require the teacher to be teacher, guidance counselor, and social worker simultaneously. When teachers are given the additional goal of implementing Whole Language in their classrooms, the media specialist must be ready to help manage the change. Teachers alone cannot be expected to be aware of all the currently available learning resources, as well as what are emerging resources and technologies. Teachers can come to rely on the media specialist to locate, acquire, organize, and teach teachers how to use them, as well as to teach students the same skills within the context of Whole Language. The successful media specialist will need to be conversant in Whole Language as a philosophy and an evolving set of practices. In the past, she was looked upon as an isolated resource, rather than as a planning partner. She was someone who taught library skills and organized books and reference resources. She was the person who gave teachers a free planning period once a week. In a Whole Language school, the first change that is made is in terms of her role and responsibilities. She needs to move beyond isolation into a more central role of cooperative program planning and team teaching. The process will involve "providing personalized information for specific teachers' needs and facilitating each teacher's use of the new program by clarifying meaning and solving individual problems."13 The media specialist will become an instructional leader if she has the vision of what Whole Language can accomplish coupled with a clear understanding of the school, the curriculum, and the community. Whole Language must be understood in the context of the correct strategies. This involves very real shifts in the perception of how children learn and how the environment for the learner is prepared, in the active observation by teachers of the learners, and in the concurrent cooperative planning among teacher, student, and librarian. When Whole Language is adopted across the curriculum and/or throughout a school, it will become necessary for the media specialist to move beyond the boundaries of her library media center into the classroom, into the community, and beyond. She will be called upon to bring the community and world into the school through knowledge of real resources, telecommunications, and emerging technology. Beyond being a coordinator of educational resources, though, she must stand as an advocate for the children in her care. She must advocate the children's right to real literature experiences as such, rather than as a mere part of a unit on a given topic. She

must also help teachers remember that children have the right to a fantasy life lived through literature and that the library media center is the rightful place for a child to continue that experience. The library media center should continue to be a haven for children, where they can explore literature on their own without judgment and without pressure. It can continue to be a place where children learn that seeking and finding information for the sheer joy of it is possible.

\section{Conclusion}

The librarian-teacher can be a valuable resource person and provide the instruments for meaningful change by casting a critical eye at the professional collection she usually maintains for the other members of a school's faculty. If she is the first to decide that Whole Language is worthy of investigating for her school, she can buy and make available titles recommended in current library and reading journals. She can start a file of reprints from teaching magazines and research journals on the topic. She should visit schools that are implementing Whole Language and invite speakers to her school. She can join a TAWL and share the literature that they publish. Electronic bulletin boards, such as Micronet in North Carolina, are a way for media specialists to communicate with others and share ideas, ask questions and become informed on current local practices using Whole Language as the framework. Most of all, the teacherlibrarian needs to understand what Whole Language is, what it isn't and, because she is the expert on her school as a community, if Whole Language would work or not.

Jeanette Veatch captures this new vision of where teacherlibrarians fit into the whole language revolution: "You have a tradition of allegiance to individualized student choice and learning, to a multiplicity of information sources, viewpoints,

\section{SALEM PRESS/MAGILL BOOKS "Reputation for Reference"}

Don't Miss These ImPORTANt New And ForthCOMing Titles

\begin{tabular}{|c|c|c|}
\hline TIME & AVAILABLE & PRE-PUB PRICE \\
\hline \multicolumn{3}{|l|}{$\begin{array}{l}\text { CRITICAL SURVEY OF LONG FICTION, } \\
\text { English Language Series }\end{array}$} \\
\hline Revised.1991 ( 8 volumes) & July, 1991 & $\begin{array}{l}\$ 400.00 \\
\text { (\$475.00 atter 10/191) }\end{array}$ \\
\hline $\begin{array}{l}\text { GREAT EVENTS FROM HISTORY II, } \\
\text { Science } \& \text { Technology ( } 5 \text { volumes) }\end{array}$ & August, 1991 & $\begin{array}{l}\$ 318.00 \\
\text { (\$375.00 after 11/1/91) }\end{array}$ \\
\hline $\begin{array}{l}\text { SURVEY OF SOCIAL SCIENCE, } \\
\text { Economic Series ( } 5 \text { volumes) }\end{array}$ & October, 1991 & $\begin{array}{l}\$ 318.00 \\
\text { (\$375.00 after 2/1/92) }\end{array}$ \\
\hline
\end{tabular}

CRITICAL SURVEY OF POETRY,

English Language Series

Revised, 1992 (8 volumes)

May, $1992 \quad \$ 400.00$

(\$475.00 after 11/30/92)

THE TWENTIETH CENTURY, GREAT ATHLETES (20 volumes). 1500 photos/graphics/ charts Reading level: Grade 6 and up

February, $1992 \$ \$ 340.00$

( $\$ 400.00$ after $7 / 1 / 92$ )

To order or for more information, contact your N.C. Representatives:

Ralph M. Davis

P.O. Box 144

Rockingham, NC 28379

Telephone: (919) $997-4857$

Fax: (919) 997-3837
Bob Jarrett

P.O. Box 717

Marion, NC 28752

Telephone: (704) 652-4262

Fax: (704) 652-4262 
and communication formats. You, among all your peers in the school, may be best equipped to understand, interpret, and model the whole language approach to teaching and learning." 14

\section{References}

1 Bess Atlwerger, Carole Edelsky and Barbara Flores, "Whole Language: What's New?," Reading Teacher 41 (November 1987): 144-54.

2 Bernice Cullinan, "Latching on to Literature: Reading Initiatives Take Hold," School Library Journal 35 (April 1989): 27.

3 Gordon Wells, The Meaning Makers (Portsmouth, NY: Heinemann, 1988), xii.

${ }^{4}$ Jim Trelease, The Read-aloud Handbook (New York: Viking Penguin, Inc., 1979).

5 Kenneth Goodman, What's Whole in Whole Language (Portsmouth,N.H.: Heinemann, 1986).

6 Cullinan, 28.

7 Ibid., 29.

8 Atlwerger.

9 Maria Montessori, The Montessori Method: the 1912 Text. Translated by Anne E. George (New York: Schocken Books, 1964), 310.

10R. C. Orem, and Marjorie F. Cobern, Montessori: Prescription for Children with Learning Disabilities (New York: Capricorn Books, G.P Putnam's Sons, 1978), 50.

11 Elizabeth Hainstock, The Essential Montessori: An Introduction to the Woman, the Writing, the Method and the Movement (New York: New American Library, 1986), 83.

12Jean Brown, "Navigating the ' 90 's - the Teacher-librarian as Change Agent," Emergency Librarian 19 (SeptemberOctober 1990): 22.

13 Shirley Hord, and Leslie Huling-Austin, "Effective Curricu-

\section{DAVIDSON TITLES, INC.}

\author{
P.O. Box 3538 \\ Jackson, TN 38303-0538 \\ (800) 433-3903 - FAX: 1-901-664-9040
}

\begin{tabular}{|c|c|}
\hline \multicolumn{2}{|c|}{ "Serving the country since 1980" } \\
\hline $\begin{array}{r}\text { August House } \cdot \\
\text { Dareborn Trade } \cdot \mathrm{E} \\
\text { IGD Books } \cdot \mathrm{R} \\
\text { National T } \\
\text { Peter Be } \\
\text { TAB Books } \\
\text { University of } \\
\text { Gareth St } \\
\text { Twenty-fir } \\
\text { Millbrook Press } \\
\text { Paragon House } \bullet\end{array}$ & $\begin{array}{l}\text { a House } \text { - Chelton } \\
\text { - Greenhaven Press } \\
\text { ublishing Group } \\
\text { k Company } \\
\text { Company } \\
\text { Publications } \\
\text { Carolina Press } \\
\text { Publishing } \\
\text { tury Books } \\
\text { ker Publications } \\
\text { Press - Nolo Press }\end{array}$ \\
\hline $\begin{array}{l}\text { Bob Rinaldi Local } R \\
\text { 1827 Paces River Avenue } \\
\text { Bldg. 13, Apt. } 104 \\
\text { Rock Hill SC } 29732 \\
\text { (803) 324-0838 }\end{array}$ & $\begin{array}{l}\text { tatives: } \\
\text { Ansley Brown } \\
\text { 1824-A North Elm Street } \\
\text { Greensboro, NC } 27408 \\
\text { (919) 275-6656 }\end{array}$ \\
\hline
\end{tabular}

$164-$ Fall 1992 lum Implementation: Some Promising New Insights," The Elementary School Journal 87 (September 1986): 106.

14Jeanette Veatch, "En Garde, Whole Lanugage," in School Library Media Annual: 1989 (Englewood, Col.: Libraries Unlimited, 1988), 11.

\section{Bibliography}

Whole Language:

its implications for the classroom

Fountas, Irene C. and Irene L. Hannigan. "Making Sense of Whole Language: Pursuit of Informed Teaching." Childhood Education 65 (Spring 1989): 133-37.

Goodman, Kenneth, E. Brooks Smith, Robert Meredith and Yetta Goodman. Language and Thinking in School: A WholeLanguage Curriculum. New York: Richard C. Owen Publisher, 1987.

Manning, Gary and Maryann Manning, eds. Whole Language: Beliefs and Practices. K-8. West Haven, Conn.: National Education Association, 1987.

Newman, Judith M. and Susan Church. "Myths of Whole Language." The Reading Teacher 44 (September 1990): 20-26.

Smith, Frank, ed. Psycholinguists and Reading. New York: Holt, Rinehart and Winston, 1973.

Tunnell, Michael O. and James S. Jacobs. "Using 'Real' Books: Research Findings on Literature-based Reading Instruction." Reading Teacher 43 (March 1989): 470-77.

Weaver, Constance, ed. Reading Process and Practice: From SocioPsycholinguistics to Whole Language. Portsmouth, N.H.: Heinemann, 1988.

\section{Whole language: its implications for the} school library media center

Barron, Daniel D. "Whole Language and Literature-based Reading: May Day! " School Library Media Activities Monthly 6 (May 1990): 51-54.

Baskin, Barbara and Karen Harris. "Stories Caught in the Web." School Library Joumal 37 (August 1990): 104.

Egnor-Brown, Rose. "Literature Based-language Arts: Toward a Cooperative Venture." Ohio Media Spectrum 41 (Winter 1989): 34-36.

Harper, Joan. "The Teacher-librarian's Role in Literature-based Reading Programs." Emergency Librarian 17 (NovemberDecember 1989): 17-20.

Haycock, Ken."Whole Language: Issues and Implications." Emergency Librarian 17 (November-December 1989): 22-26.

Henri, James. "The Integrated Approach to School Library Programming." Emergency Librarian 14 (January-February 1987): 14.

Hodge, Francis. "Taking the Drill Out of Reading." Publishers Weekly (20 January): 99-100.

Kalb, Virginia. "Using Literature in an Integrated Language Arts Program for Beginning Readers." School Library Media Ouarterly (Winter 1989): 90-91.

Miller, Larry. "School Librarians and the Teaching of Reading." Canadian Library Journal 37 (April 1980): 113.

School Library Media Annual: 1989. Englewood, Col.: Libraries Unlimited, 1988.

Stahlschmidt, Agnes. "The Whole Language Approach: Special Supplement: Support for the Whole Language Program - What the Library Media Specialist Can Do." School Library Media Activities Monthly 6 (December 1989): 31.

Walla, Kay. "Rx for Library-Media Specialist in Support of Writing and Reading: The Whole Language Approach." Ohio Media Spectrum 41 (Winter 1989): 29-33.

Zola, Meguido. "The Tao of Whole Language." Emergency Librarian 17 (November-December 1989): 9-15. 


\section{Manage, search, and find with a few keys...}

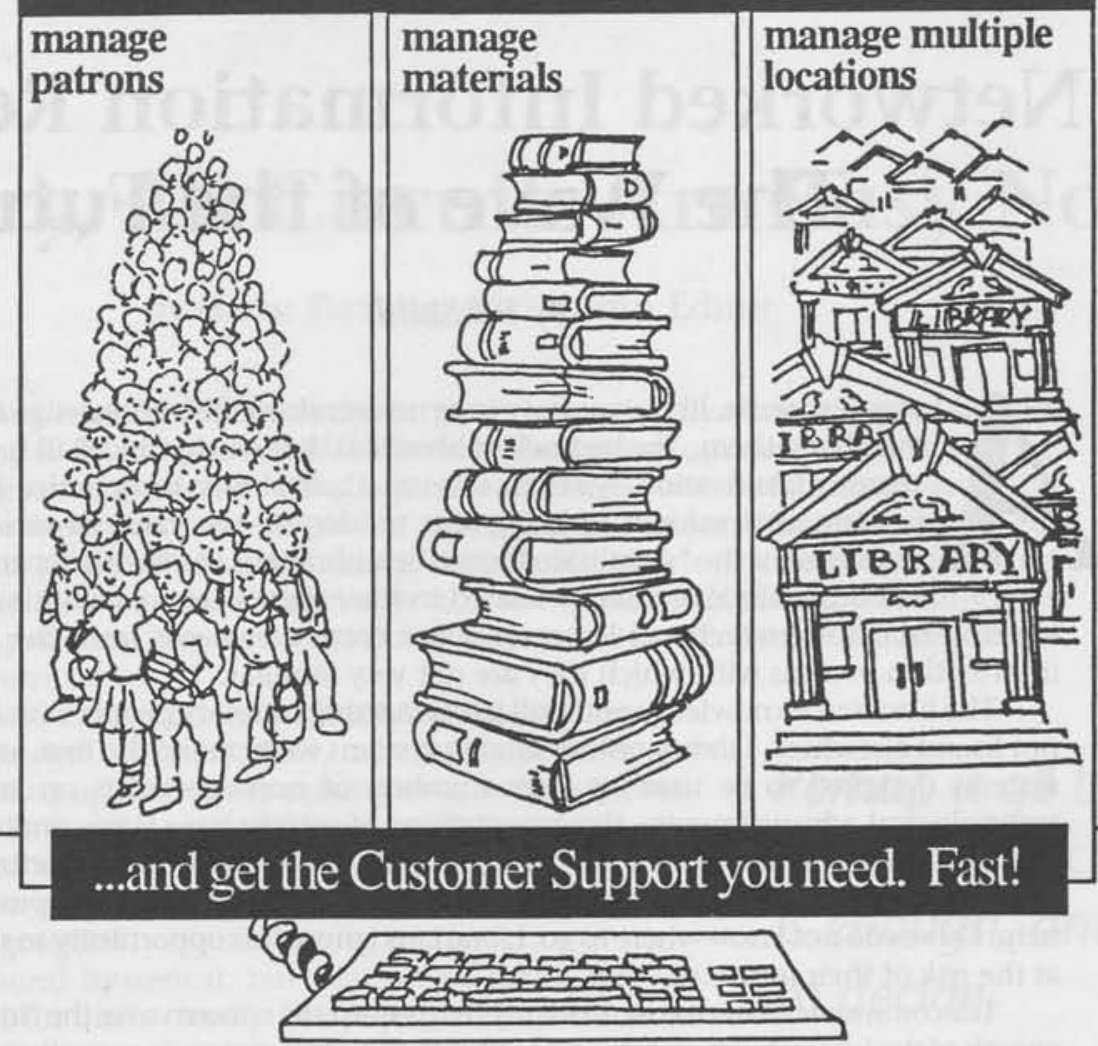

Managing your library, patrons, and materials is easier than ever with Winnebago Software. With Winnebago, you get the sophistication to handle all of your demanding library automation needs.

- Winnebago CIRC keeps track of up to 100,00 patrons. It even creates overdues and statistics reports, and has built in control for textbook or special collection circulation.

- Winnebago CAT lets patrons look up materials by key words or phrases, subjects, authors, titles or notes. Approximate or partial spellings are no problem for Winnebago CAT!

- Have multiple locations to manage? Winnebago Union CAT lets you do it easily, from finding materials in any library location to creating centralized library reports.

Ease of use and unparalleled customer service are just as important as advanced features. That's why, if you ever need assistance, our Customer Support staff will call you back in two hours or less. It's a commitment only Winnebago makes!

For more information on Winnebago Software products and services, call 1-800-533-5430, extension A95. We'll also send you a FREE copy of the information-packed Guide to Library Automation: A Step-by-Step Introduction.

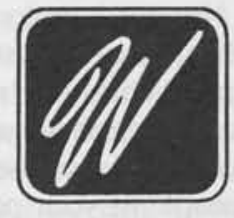

1-800-533-5430, ext. A95

or call your local representative

East Educational Services at 803-781-4416

Winnebago Software Company 